\title{
Vibratory Compaction Tests on Graphite Powders for Neutron Shielding
}

W. C. Morgan

May 1982

Prepared for

Hanford Engineering Development Laboratory under a related services agreement with the U.S. Department of Energy under Contract DE-AC06-76RLO 1830, Work Order No. B05905

Pacific Northwest Laboratory Operated for the U.S. Department of Energy by Battelle Memorial Institute 


\title{
DISCLAIMER
}

This report was prepared as an account of work sponsored by an agency of the United States Government. Neither the United States Government nor any agency thereof, nor any of their employees, makes any warranty, express or implied, or assumes any legal liability or responsibility for the accuracy, completeness, or usefulness of any information, apparatus, product, or process disclosed, or represents that its use would not infringe privately owned rights. Reference herein to any specific commercial product, process, or service by trade name, trademark, manufacturer, or otherwise, does not necessarily constitute or imply its endorsement, recommendation, or favoring by the United States Government or any agency thereof. The views and opinions of authors expressed herein do not necessarily state or reflect those of the United States Government or any agency thereof.

\author{
PACIFIC NORTHWEST I.ABORATORY \\ operated by \\ BATTELLE \\ for the \\ UNITED STATES DEPARTMENT OF ENERGY \\ under Contract DE-AC06-76RLO 1830
}

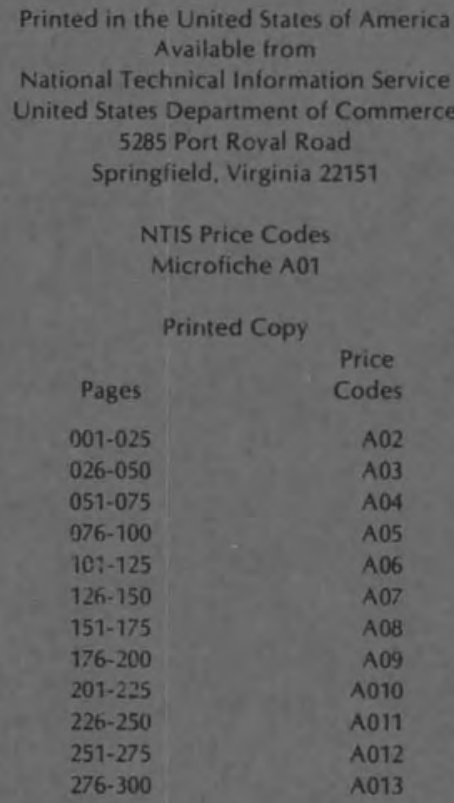


PNL-4258

UC-20C

VIBRATORY COMPACTION TESTS ON GRAPHITE

POWDERS FOR NEUTRON SHIELDING

W. C. Morgan

May 1982

Prepared for Hanford Engineer ing Development Laboratory under a related services agreement with the U.S. Department of Energy under Contract DE-AC06-76RLO 1830, Work Order №. B05905

Pacific Northwest Laboratory

Richland, Washington 99352 


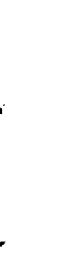


Mixtures of three size ranges of graphite powders have been vibratory packed to densities as high as $1.40 \mathrm{gm} / \mathrm{cm}^{3}$, which is 87.5 percent of the design density for the graphite segment of the FMIT test cell shield. U1trasonic resonance vibration of the particles was determined to be an impractical method for achieving the required density. Possible options for fabricating the shield are: 1) revert to solid graphite, rather than vibratory packed powder, or 2) develop the mechanical vibratory compaction method, which would require a) designing for the higher heat-load attendant with the reduced graphite density, or b) increasing the thickness of the graphite segment by 15 percent or c) seeking a new source of graphite powder with higher particle density. 


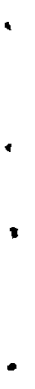


CONTENTS

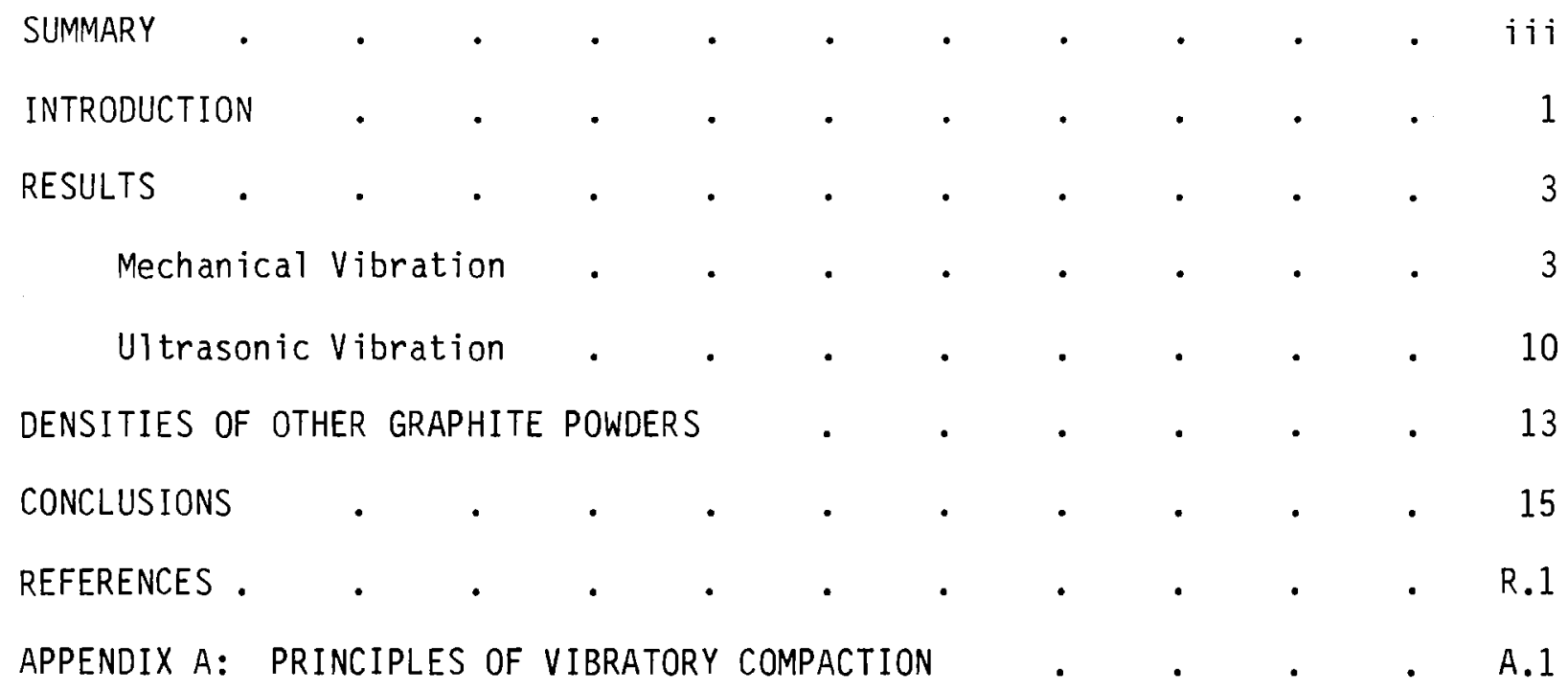

v 


\section{FIGURES}

1 Micrographs of Graphite Particles (approx. 2.5x magnification).

a) Plus 4 mesh particles; b) Minus 8, plus 20 mesh particles;

c) Minus 60 , plus 270 mesh particles.

2 Pneumatic Vibratory Compaction Apparatus. $\quad$. $\quad$. $\quad$. $\quad 6$

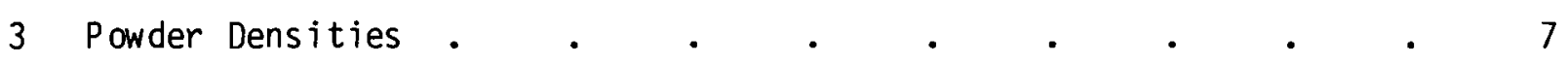

\section{TABLES}

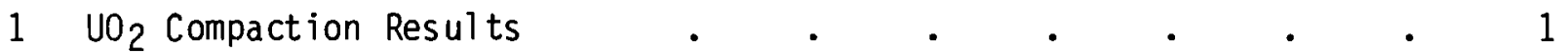

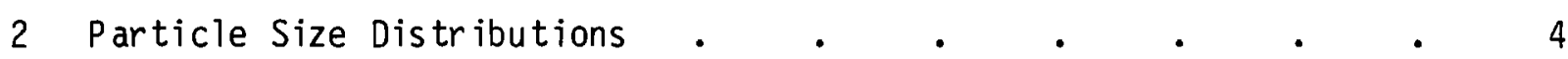

3 Densities of Particles and Packed Powders . . . . . 8

4 Comparison of Calculations and Results on Two Component

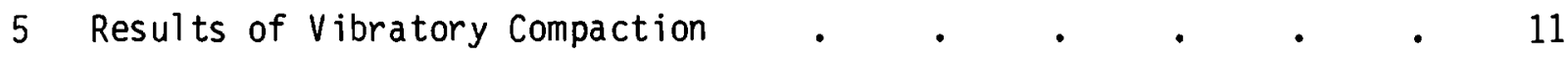

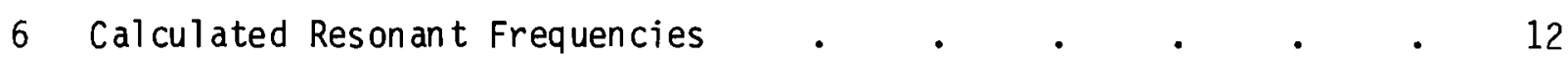

7 Densities Obtained with Other Graphite Powders . . . . . . 14

A.1 Maximum Packing Efficiencies Obtained by Ayer and Soppet - . A.3

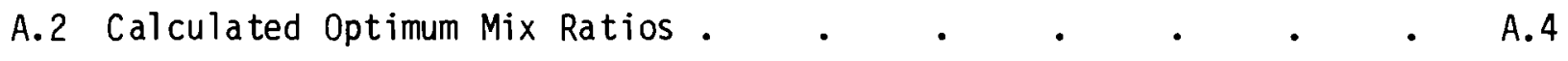




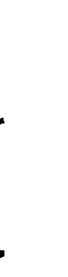




\section{INTRODUCTION}

The current design (a) for the neutron shield panels for the test cells of the Fusion Materials Irradiation Test Facility (FMIT) calls for a massive sandwich structure composed of a graphite layer enclosed in cast steel. The use of densely packed graphite powders rather than machined solid graphite sections could result in a savings in cost, (b) and an increase in performance. ${ }^{(c)}$ Bulk density of the graphite was specified to be $1.60 \mathrm{gm} / \mathrm{cm}^{3}$; although this is only 71 percent of the theoretical density for graphite crystals, it is considerably higher than can be obtained using normal mechanical pack ing techniques.

Vibratory compaction techniques, however, have been used to routinely produce $\mathrm{UO}_{2}$ fuel compacts with densities between 85 and 89 percent of theoretical (crystalline) density. For example, Table 1 shows results reported by Hauth (1967) on vibratory compaction of crushed particles of high density $\mathrm{UO}_{2}$.

The ceramic powders used to ob ta in the high vibratory compacted densities have had particle densities very nearly equal to the theoretical (crystalline) densities; in general, the crushed particles were quite angular, but had a small length-to-diameter ratio. Attainment of these densities requires particles in three distinct size ranges (coarse, medium, and fine), chosen such that the medium size particles can infiltrate the spaces between coarse particles and the fine particles can infiltrate the remaining spaces (see Appendix A). Infiltration of the particles has been accomplished by vibrating the container so the particles migrate under the combined forces of inertia and gravity. However, in the present application, the shield assembly will weigh several tens of tons; thus, it will not be feasible to vibrate the entire assembly.

(a) The Ralph M. Parsons Co., "Bas is of Design for Building and Utilities General - Test Cell Cool ing," BOD-00-PR-4, Rev. 1, issued 5/19/81.

(b) Memo from W. C. Morgan to W. L. Knecht, "Vibratory Pack ing Program Estimated Costs," dated July 30, 1981.

(c) Memo from W. C. Morgan to M. 0. Rau, "FMIT Test Cell Shielding," dated Jan. 27, 1981 . 
TABLE 1. $\quad \mathrm{UO}_{2}$ Compaction Results

\begin{tabular}{|c|c|c|c|c|c|c|}
\hline \multicolumn{3}{|c|}{ Mesh Designation $(*)$} & \multicolumn{3}{|c|}{ Mix, Weight Percent } & \multirow{2}{*}{$\begin{array}{l}\text { Percent of } \\
\text { Theoretical }\end{array}$} \\
\hline Coarse & Medium & Fine & Coarse & Vediu & Fine & \\
\hline$(\star \star) / 4$ & $12 / 16$ & -100 & 69 & 14 & 17 & 95 \\
\hline $4 / 6$ & $20 / 30$ & $100 / 270$ & 68 & 15 & 17 & 88 \\
\hline $6 / 8$ & $30 / 40$ & $100 / 200$ & 63 & 18 & 19 & 90 \\
\hline $6 / 8$ & $30 / 40$ & -325 & 77 & 10 & 13 & 93 \\
\hline $12 / 14$ & $50 / 70$ & -200 & 65 & 15 & 20 & 87 \\
\hline $12 / 16$ & $50 / 70$ & -400 & 77 & 10 & 13 & 90 \\
\hline $14 / 16$ & $60 / 80$ & -200 & 68 & 15 & 17 & 87 \\
\hline
\end{tabular}

(*) U.S. Standard Sieve Specification; see: "E11, Standard Specification for Wire-Cloth Sieves for Testing Purposes, "Annual Book of ASTM Standards, Part 26. Hauth reported the Tyler screen designations .

(**) U.S. Standard $6.7 \mathrm{~mm}$ sieve designation.

An al ternate approach, which evidently has not been utilized before, is to transmit the vibration directly through the particles. Movement of the particles can be produced by mechanical vibration in the sonic range, or by exciting the resonant vibrational frequency of the particles in the ultrasonic range.

The scope of the present investigation was to:

1) Determine the blend of particle size fractions required to obtain a dense compact.

2) Determine the maximum compacted density of the blend and determine the sonic frequencies, vibrational modes, and power input required to efficiently compact the powders. 
Several companies market large quantities of calcined cokes and/or small quantities of graphite powders, produced by machining finished pieces of graphite. However, at present, Union Carbide ${ }^{(a)}$ is the only company which supplies standard grades of graphitized petroleum coke powders in the quantities required for the FMIT test cell shielding. Although it would be possible to either graphitize the calcined cokes or arrange for the purchase of larger quantities of the machined graphite powders, the lead-time required was deemed to be excessive in view of the schedule projected for the FMIT at the start of the tests. Therefore, three grades of graphitized coke powders were obtained from Union Carbide; the powders were evidently all from one coke lot (5 NNC 6680), the grade designations indicate the nominal range of particle sizes. Table 2 lists the particle size distributions measured on the three grades of powders.

Figure 1 shows typical particle shapes for screened fractions of the powders; particle shapes and length/diameter ratios appear quite similar to those of the $\mathrm{UO}_{2}$ powders shown by Hauth (1962) and to the ball-milled malleable-steel grit used by Ayer and Soppet (1966).

Mechanical Vibration

A mechanical (pneumatic) vibrator, shown in Figure 2, was constructed; the clear plastic tube is $6.35 \mathrm{~cm}$ diameter by $45 \mathrm{~cm}$ high, and is marked at about $39 \mathrm{~cm}$. Volume to the mark, measured by filling with water at $24.5^{\circ} \mathrm{C}$, was $1238 \mathrm{~cm}^{3}$. A sliding-fit nylon plug $(259 \mathrm{gm})$ rests on the powder during compaction. Vibrational frequency and amplitude are not independently variable, except to a very limited extent, with this apparatus; but, in most cases, a combination was easily found to produce rapid compaction of the powders.

Figure 3 shows typical densities after 1) pouring the powder into the tube, 2) vibrating the poured powder (with additions of more powder to fill the tube to the mark), and 3) vibrating the tube during the pour. It can be seen for all three size fractions that vibration during the pour resulted in the highest densities.

(a) Union Carbide Corporation, Carbon Products Division, Chicago, IL 60606. 
TABLE 2. Particle Size Distributions

\begin{tabular}{|c|c|c|c|c|c|c|c|c|c|c|c|c|c|c|c|}
\hline \multirow{2}{*}{\multicolumn{2}{|c|}{ Mesh (a) }} & \multirow{2}{*}{$\begin{array}{c}\text { Sieve } \\
\text { Opening } \\
\mathrm{mm} \\
\end{array}$} & \multicolumn{3}{|c|}{ BB-7 } & & \multirow{2}{*}{$\begin{array}{c}\text { Sieve } \\
\text { Open ing } \\
\text { mm } \\
\end{array}$} & \multicolumn{3}{|c|}{$B B-5$} & & \multirow{2}{*}{$\begin{array}{c}\text { Sieve } \\
\text { Opening } \\
\mathrm{mm} \\
\end{array}$} & \multicolumn{3}{|c|}{$\mathrm{BB}-1$} \\
\hline & & & $81-3(b)$ & $\begin{array}{l}\text { Cumu } \\
81-3 \\
\end{array}$ & $\begin{array}{l}\text { lative } \\
81-6(c)\end{array}$ & Mesh & & $81-2(b)$ & $\frac{\text { Cumu }}{81-2}$ & $\begin{array}{l}\text { ative } \\
81-5(\mathrm{c}) \\
\end{array}$ & Mesh & & $81-1(b)$ & $\begin{array}{c}\text { Cumul } \\
81-1 \\
\end{array}$ & $\frac{\text { tive }}{81-4(d)}$ \\
\hline & +4 & 4.75 & 34.0 & 34.0 & 39.6 & +20 & 850 & 0.9 & 0.9 & & +140 & 106 & 6.1 & 6.1 & \\
\hline & 5 & 4.00 & 35.3 & 69.3 & & 25 & 710 & 1.5 & 2.4 & & 170 & 90 & 6.3 & 12.4 & 10.8 \\
\hline & 6 & 3.25 & 19.6 & 88.9 & & 30 & 600 & 1.7 & 4.1 & & 200 & 75 & 11.4 & 23.8 & \\
\hline & 7 & 2.80 & 6.2 & 95.1 & & 35 & 500 & 2.2 & 6.3 & 1.9 & 230 & 63 & 3.5 & 27.3 & \\
\hline & 8 & 2.36 & 1.6 & 96.7 & 98.0 & 40 & 425 & 8.1 & 14.4 & & 270 & 53 & 16.6 & 43.9 & \\
\hline$D$ & -8 & & 3.3 & 100.0 & 100.0 & 45 & 355 & 15.1 & 29.5 & & 325 & 45 & 9.3 & 53.2 & \\
\hline & & & & & & 50 & 300 & 15.8 & 45.3 & & 400 & 38 & 8.0 & 61.2 & 63.5 \\
\hline & & & & & & 60 & 250 & 13.1 & 58.4 & & -400 & & 38.8 & 100.0 & 100.0 \\
\hline & & & & & & 70 & 212 & 13.1 & 71.5 & & & & & & \\
\hline & & & & & & 80 & 180 & 7.9 & 79.4 & 78.3 & & & & & \\
\hline & & & & & & -80 & & 20.6 & 100.0 & 100.0 & & & & & \\
\hline
\end{tabular}

a) U.S. Standard Sieve Specification.

b) One quart can of powder.

c) 70 lb bag of powder; riffled prior to sampling.

d) 60 lb bag of powder; riffled prior to sampling. 


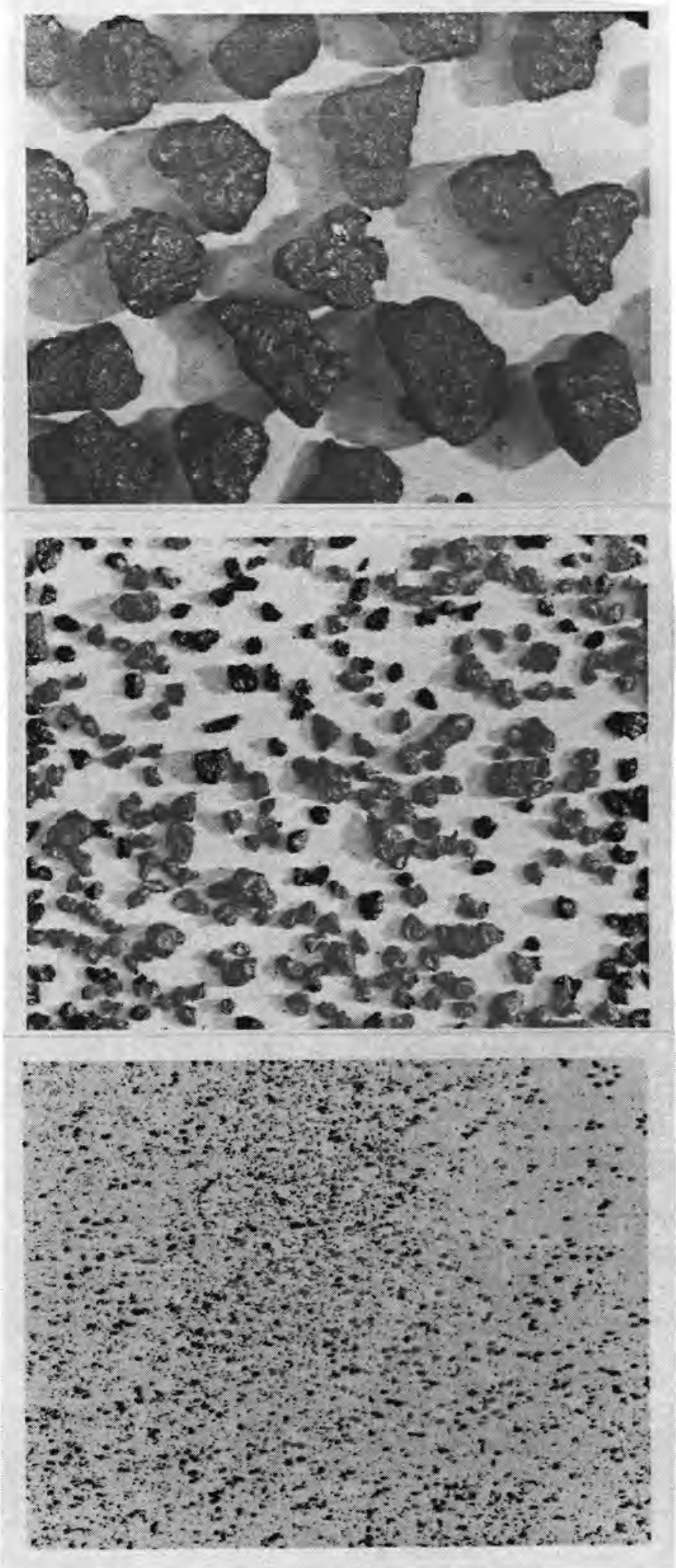

a) Plus 4 mesh particles

b) Minus 8 , plus 20 mesh particles

c) Minus 60, plus 270 mesh particles

FIGURE 1. Micrographs of Graphite Particles (approx. $2.5 \times$ magnification) 


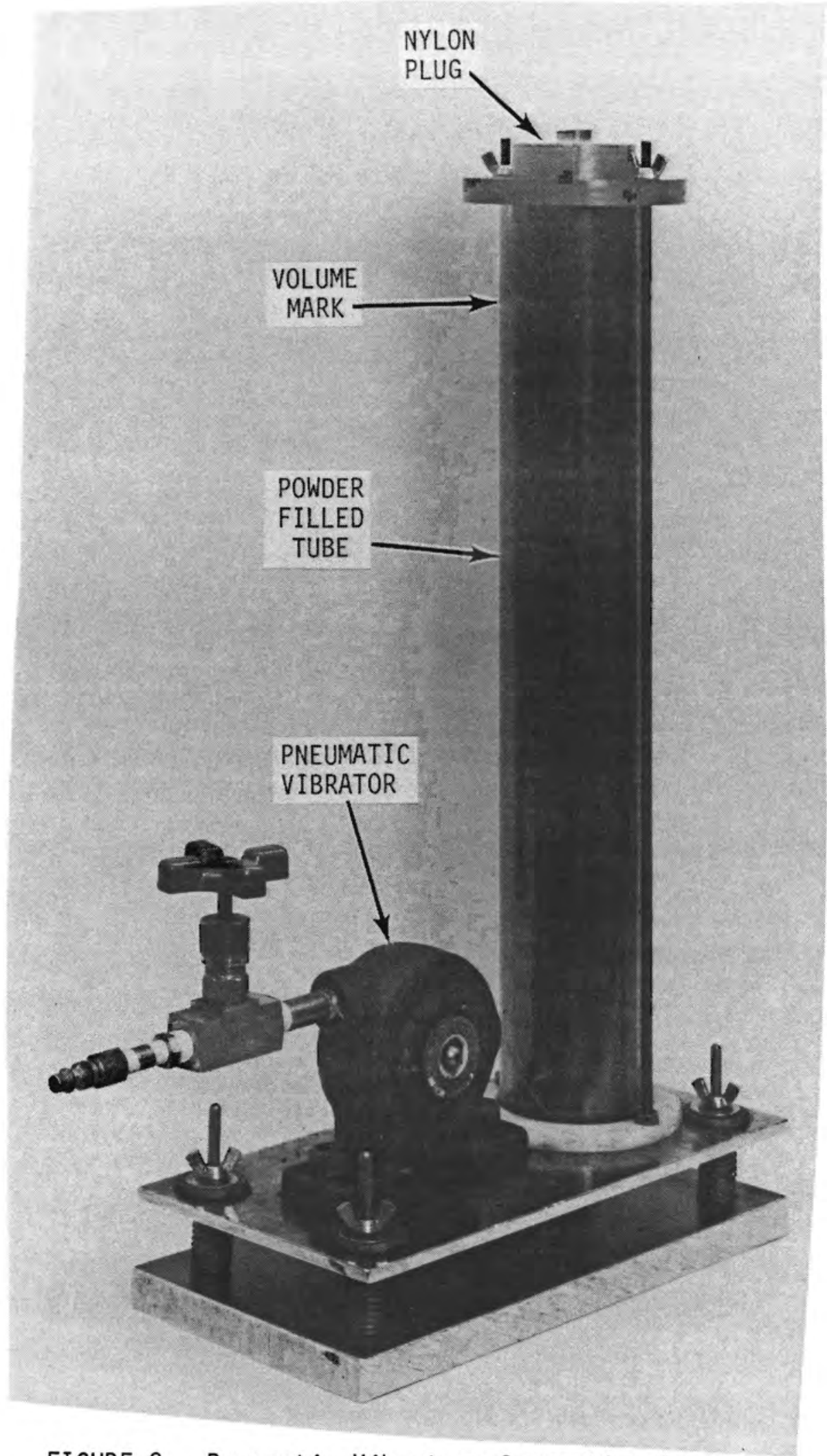

FIGURE 2. Pneumatic Vibratory Compaction Apparatus 


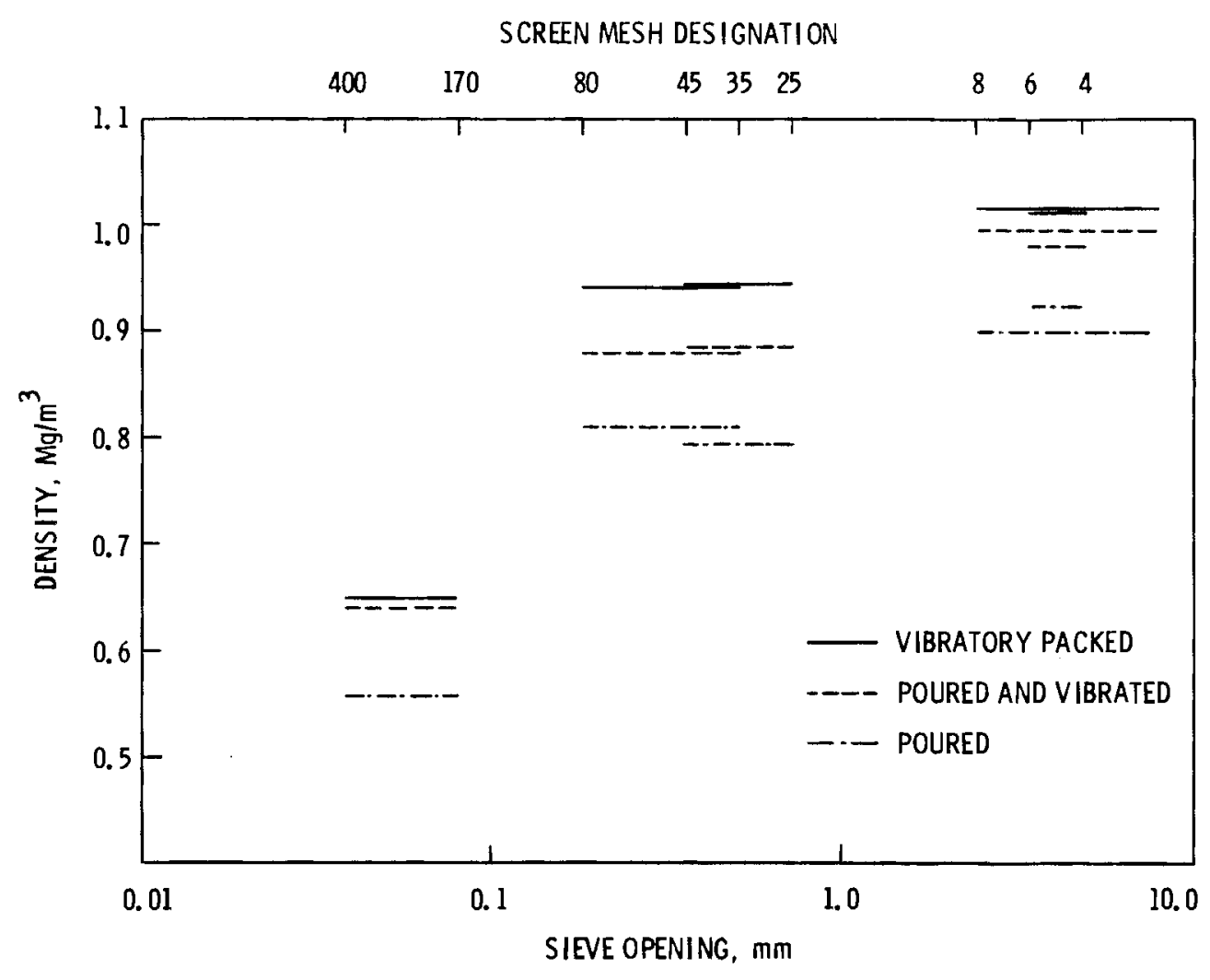

FIGURE 3. Powder Densities

Table 31 ists the bulk densities obtained by pouring the powders during vibratory compaction, and the particle densities obtained by water displacement. The pycnometric procedure for measuring the particle density was as follows:

1) A weighed amount of graphite powder was placed in a $100 \mathrm{ml}$ volumetric flask, and water was added;

2) The flask was agitated in an ultrasonic cleaning bath to remove all air from the powder;

3) Water was added to bring the level to the $100 \mathrm{ml}$ mark; the weight ob ta ined, and

4) Density of powder was calculated from the weight differences. 
TABLE 3. Densities of Particles and Packed Powders

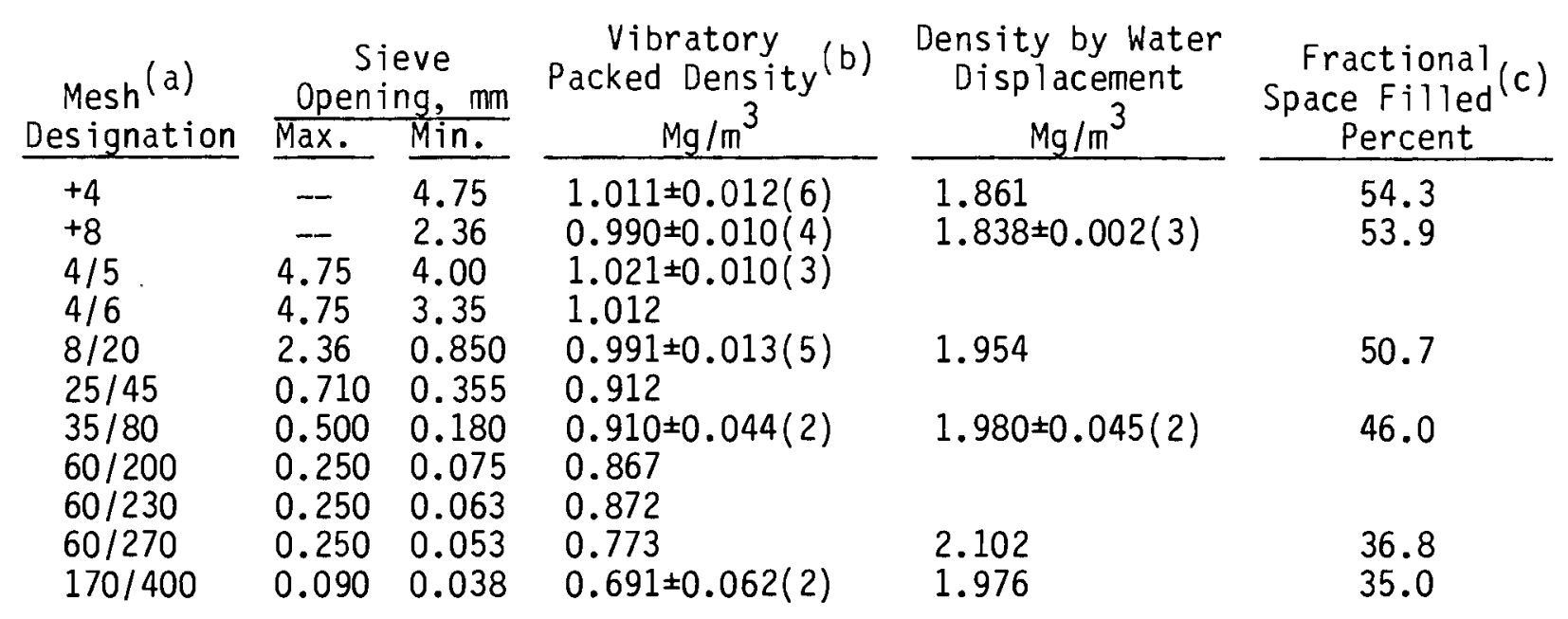

(a) Mesh designation $x / y$ indicates that the particles passed through a sieve of $x$ mesh and were retained on a sieve of $y$ mesh.

(b) Numbers in parentheses indicate number of measurements; \pm is one sigma range.

(c) The fractional space filled is the ratio of vibratory packed density/density by water displacement.

Three general trends can be seen in Table 3:

1) The particle density increases as the particle size decreases, due to elimination of internal cracks and voids in the finer sizes.

2) The vibratory packed density decreases as the particle size decreases, due to increased importance of friction and cohesive forces between the finer particles.

3) The packed density decreases as the particle size-range increases, due to increased bridging between particles.

Using the data from Table 3, we calculated optimum ratios of the particle size fractions to achieve efficient packing and high densities (see Appendix A). In practice, the densities obtained were consistently less than predicted (see Table 4). For two-part mixtures, the highest densities were obtained by vibratory packing the coarser fraction and infiltrating it with the finer fractions. If the vibrational amplitude was kept small, the height of the packed column of coarse particles remained constant during the process of infiltrating the finer 
particles into the voids; however, infiltration would invariably cease before the desired mix ratio, and density, was obtained.

On the other hand, if the vibrational amplitude was increased, the height of the column of coarse particles increased during infiltration of the fine particles; this "bulking-up" resulted in a mix ratio of the size fractions which approached the calculated optimum ratio, but the increased volume for the mixture lowered the obtainable density below that calculated for the optimum mix ratio. This is illustrated in Table 4; in these three cases the fine powder appeared to have filled the spaces between the coarser particles. In an attempt to attain the calculated optimum mix ratio, additional fine powder was added on top of the +4 and +8 mesh powders, and the vibrational amplitude was increased, causing them to bulk-up by about 1.5 percent and 3.5 percent, respectively; this had little effect on the final density, but it did change the mix ratio.

TABLE 4. Comparison of Calculations and Results on Two-Component Mixtures

\begin{tabular}{|c|c|c|c|c|c|}
\hline \multirow[b]{2}{*}{ Mix Mesh } & \multirow[b]{2}{*}{ Size } & \multicolumn{2}{|c|}{ Calculated } & \multicolumn{2}{|c|}{ Measured } \\
\hline & & $\begin{array}{l}\text { Ratio, } \\
\text { Percent }\end{array}$ & $\begin{array}{l}\text { Density } \\
\mathrm{Mg} / \mathrm{m} 3\end{array}$ & $\begin{array}{l}\text { Ratio, } \\
\text { Percent }\end{array}$ & $\begin{array}{l}\text { Density, } \\
\mathrm{Mg} / \mathrm{m} 3\end{array}$ \\
\hline+4 & $20 / 30$ & $70 / 30$ & 1.450 & $75 / 25$ & 1.357 \\
\hline+8 & $25 / 45$ & $71 / 29$ & 1.401 & $72 / 28$ & 1.336 \\
\hline $8 / 20$ & $100 / 200$ & $72 / 28$ & 1.384 & $78 / 22$ & 1.293 \\
\hline
\end{tabular}

The measured $78 / 22$ ratio for $8 / 20-100 / 200 \mathrm{mix}$ is the same as that calculated by Ayer and Soppet (1966) to be the optimum mixture for angular grit particles (see Appendix A). This result can be explained if the particle density is actually much lower than that measured by water displacement.

With the three-part mixtures (Table 5), the highest densities were obtained by infiltrating the vibratory compacted coarser fraction with a blend of the medium and fine fractions, mixed in the calculated optimum ratios. Again, however, less of the blend could be infiltrated than was expected from the calculations. Blending the three fractions always resulted in filling the container before all of the blend was added. 
Optimum mix ratios for the highest densities are very close to those obtained by Ayer and Soppet (1966) for the steel grit particles. Moreover, the powders were packed so tightly that the container could be inverted without loosing any of the powder. These results support our previous conclusion that the particle densities must be considerably lower than those measured by water displacement. If we assume that the equations developed by Ayer and Soppet (1966), for the packing efficiency of angular. steel grit, can be applied to these graphite powders, the packed density of the $4 / 5$ mesh particles is 62.4 percent of their particle density. Thus the actual density of the particles appears to be on $1 y 1.636 \mathrm{gm} / \mathrm{cm}^{3}$, much lower than the immersion density. It appears, from these results, that the coarser $(+8$ mesh) powders have internal voids which are accessible to water, but which are not accessible to the smaller particles in the fine powder fractions used in this investigation.

\section{Ultrasonic Vibration}

One of the goals of this program was to determine the optimum parameters for compacting the particles by ultrasonic vibration. The fundamental relationship for resonant vibration of a body is given by the equation:

$$
f=v / 2 l \text {. }
$$

where: $f$ is the frequency

$\nu$ is the velocity of sound in the body, and

$\ell$ is the path length for the resonant wave.

In solid pieces of several grades of artificial graphites the measured ultrasonic velocity is about $2400 \mathrm{~m} / \mathrm{s}$ (Morgan and Becker 1979). Using this velocity as the velocity of sound in the particles, and a 2.5 to 1 length-todiameter ratio, the nominal resonant frequencies for particles of different mesh size are calculated as listed in Table 6.

Three ceramic, PZT-4, transducers with resonant frequencies of 250,375 and $1000 \mathrm{kHz}$ were obtained and several types of mounting techniques were used to obtain coupling to the particles.

With the transducers mounted in the bottom of a clear plastic tube containing the paricles, particle movement was observable for a thin layer of 


\section{TABLE 5. Results of Vibratory Compaction}

\begin{tabular}{|c|c|c|c|c|c|}
\hline Mes & h Designa & tion & Fill & Density & \\
\hline Coarse & Medium & Fine & Method & $\mathrm{Mg} / \mathrm{m}^{3}$ & \\
\hline+4 & $8 / 20$ & -- & B & 1.174 & $71 / 29$ blend \\
\hline+4 & $8 / 20$ & $60 / 270$ & $A B$ & 1.342 & $2: 1$ blend (additional 60/270 infiltrated); 38/36/26 final mix \\
\hline+4 & $8 / 20$ & $100 / 200$ & B & 1.329 & $61 / 28 / 12$ blend \\
\hline+4 & $8 / 20$ & $100 / 200$ & A & 1.387 & $61 / 28 / 12 \operatorname{mix}$ \\
\hline+4 & $12 / 20$ & $100 / 200$ & AI & 1.401 & $2: 1$ coarse/med; infiltrated with $100 / 200$ \\
\hline+4 & $20 / 30$ & -- & I & 1.326 & $70 / 24$ final $\operatorname{mix}$ \\
\hline+4 & $20 / 30$ & $120 / 200$ & B & 1.347 & $60 / 27 / 12$ blend \\
\hline+4 & $30 / 40$ & $120 / 200$ & IB & 1.403 & $27.6 \%$ of $2: 0.9$ blend; $72 / 19 / 9$ final mix \\
\hline+8 & $25 / 45$ & -- & I & 1.336 & $72 / 28$ final mix \\
\hline+8 & $35 / 80$ & -- & A & 1.333 & $70 / 30$ final mix \\
\hline $4 / 5$ & $35 / 45$ & $170 / 230$ & IB & 1.355 & $25.3 \%$ of $1: 1$ blend; $75 / 13 / 13$ final mix \\
\hline $4 / 5$ & $35 / 45$ & $170 / 230$ & IB & 1.377 & $25.1 \%$ of $3: 2$ blend; $75 / 15 / 10$ final mix \\
\hline $4 / 5$ & $35 / 45$ & $170 / 230$ & IB & 1.396 & $27.1 \%$ of $2: 1$ blend; $73 / 18 / 9$ final $\mathrm{mix}$ \\
\hline $4 / 5$ & $35 / 45$ & $170 / 230$ & $A B$ & 1.338 & $2: 1$ blend of medium and fine \\
\hline $4 / 5$ & $35 / 45$ & $170 / 230$ & A & 1.393 & Additions adjusted so that fractions infiltrated \\
\hline $4 / 5$ & $3 b / 45$ & $170 / 230$ & $A B$ & 1.367 & Blend from above packing test \\
\hline $4 / 5$ & $35 / 45$ & $170 / 400$ & $A B$ & 1.307 & $1: 1$ blend; approx. $1: 1$ coarse/blend \\
\hline $4 / 5$ & $35 / 45$ & $170 / 400$ & $A B$ & 1.350 & $1: 1$ blend; approx. $3: 2$ coarse/blend \\
\hline $4 / 6$ & $20 / 30$ & -- & B & 1.230 & $67 / 33$ blend \\
\hline $4 / 6$ & $20 / 30$ & -- & B & 1.237 & $69 / 31$ blend \\
\hline $4 / 6$ & $20 / 30$ & -- & B & 1.229 & $71 / 29$ blend \\
\hline $4 / 6$ & $20 / 30$ & $120 / 200$ & B & 1.307 & $61 / 28 / 11$ blend \\
\hline-- & $8 / 20$ & $60 / 270$ & B & 1.187 & $67 / 33$ blend \\
\hline-- & $8 / 20$ & $100 / 200$ & I & 1.293 & $78 / 22$ final mix \\
\hline- & $35 / 45$ & $170 / 400$ & B & 1.011 & $50 / 50$ blend \\
\hline
\end{tabular}

\footnotetext{
$B=$ blended: $A B=$ alternate layers of coarse, followed by blend of medium and $f$ ine;

$A=$ alternating layers; $A I=$ alternating layers of coarse and medium, infiltrated with fine;
} IB = packed coarse infiltrated with blend of medium and fine; I = infiltrated. 
TABLE 6. Calculated Resonant Frequencies

\begin{tabular}{|c|c|c|c|}
\hline $\begin{array}{c}\text { Mesh } \\
\text { Designation }\end{array}$ & $\begin{array}{c}\text { Mesh } \\
\text { Opening, mm }\end{array}$ & \multicolumn{2}{|c|}{$\begin{array}{l}\text { Resonant } \\
\text { Frequency, } \mathrm{kHz}\end{array}$} \\
\hline 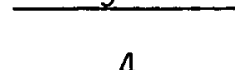 & 175 & $\frac{\text { Upper }}{255}$ & Lower \\
\hline 4 & $\begin{array}{l}4.15 \\
3.35\end{array}$ & $\begin{array}{l}255 \\
360\end{array}$ & $\begin{array}{l}100 \\
145\end{array}$ \\
\hline 0 & 2.36 & 510 & 205 \\
\hline 12 & 1.70 & 705 & 280 \\
\hline 20 & 0.85 & 1410 & 565 \\
\hline
\end{tabular}

$60 / 270$ mesh particles; however, with a $250 \mathrm{ml}$ layer of +4 mesh underneath the finer particles, the signal was attenuated to the point that no measurable change in density occurred even with the focused signal from the $375 \mathrm{kHz}$ transducer.

The input voltage to the transducers was limited to 200 volts peak-topeak, by saturation of the amplifier and the signal transmission time was limited to $15 \mathrm{~min}$ because of transducer heating. To alleviate the heating problem, the $250 \mathrm{kHz}$ transducer was bonded to an aluminum $\mathrm{plate}$ of $1 / 2$ wavelength thickness; however, no observable particle movement occurred with this configuration.

As a quick check to see if compaction could be obtained by using lower frequencies, a $40 \mathrm{kHz}$ ultrasonic cleaner was used as the driving mechanism. With a graduated cylinder immersed in the water bath, a density change of 18.5 was observed in $10 \mathrm{~min}$; when a second concentric cylinder was used to isolate the inner cylinder from contact with the water, compaction still occurred, but at a reduced rate.

It was concluded that the large attenuation of the signal at these frequencies makes resonant vibration of the particles impractical as a method of obtaining dense powder compacts. Thus, a mechanical or electromechanical impulse-type vibrator, built along the lines of those used for vibratory compaction of soils will need to be designed and constructed for this specialized application. 


\section{DENSITIES OF OTHER GRAPHITE POWDERS}

The theoretical density for crystalline graphite is $2.26 \mathrm{Mg} / \mathrm{m}^{3}$, and several forms of graphite (for example: high-temperature stress-annealed pyrolytic and pressed blocks of pure natural flake graphite) have bulk densities that closely approach the theoretical density. Other forms of graphite bodies have bulk densities in the range $1.54-1.76 \mathrm{Mg} / \mathrm{m}^{3}$, primarily as a result of porosity. Immersion densities $(a)$ are generally much higher than bulk densities; however, because of crystalline imperfections and/or inaccessible porosity, immersion densities are generally less than $2.20 \mathrm{Mg} / \mathrm{m}^{3}$. Table 7 shows some typical densities of various graphite powders (Moore, et al. 1972).

Comparison of the tap and $\mathrm{CCl}_{4}$ immersion densities shown in Table 7 with the vibratory packed and water immersion densities shown in Table 3 for the $170 / 400$ mesh powder shows that the particle densities of the powders used in this study are significantly lower than are obtainable in some other graphite powders. The lower immersion density is probably due to a lower crystalline density; if this is the case, heating to a higher graphitization temperature could alleviate the problem.

If higher density powders were obtained, one could expect that their packed density would increase in almost direct proportion to the increase in their tap densities, assuming that the tap densities were measured on the particle sizes of the coarse fraction. Assuming that an optimum mixture of coarse/medium/fine particles would lie in the neighborhood of 70/20/10 percent, respectively, small changes in the particle- or tap-densities of the two finer fractions cannot have much effect on the vibratory packed density. The data in Table 7 were obtained on the finer fractions; thus, they do not provide a direct indication of the tap densities obtainable with the coarse fractions. However, the indications are that graphite particles with much higher tap densities, than the $1.01 \mathrm{Mg} / \mathrm{m}^{3}$ which we obtained on the +4 mesh particles, are readily available.

(a) Different investigators have used various fluids to determine immersion densities; for example, water, carbon tetrachloride $\left(\mathrm{CC}_{4}\right)$, benzene, or kerosine. Immersion densities are practically independent of the fluid used, provided that it has a low surface tension. 
TABLE 7. Densities Obtained with Other Graphite Powders

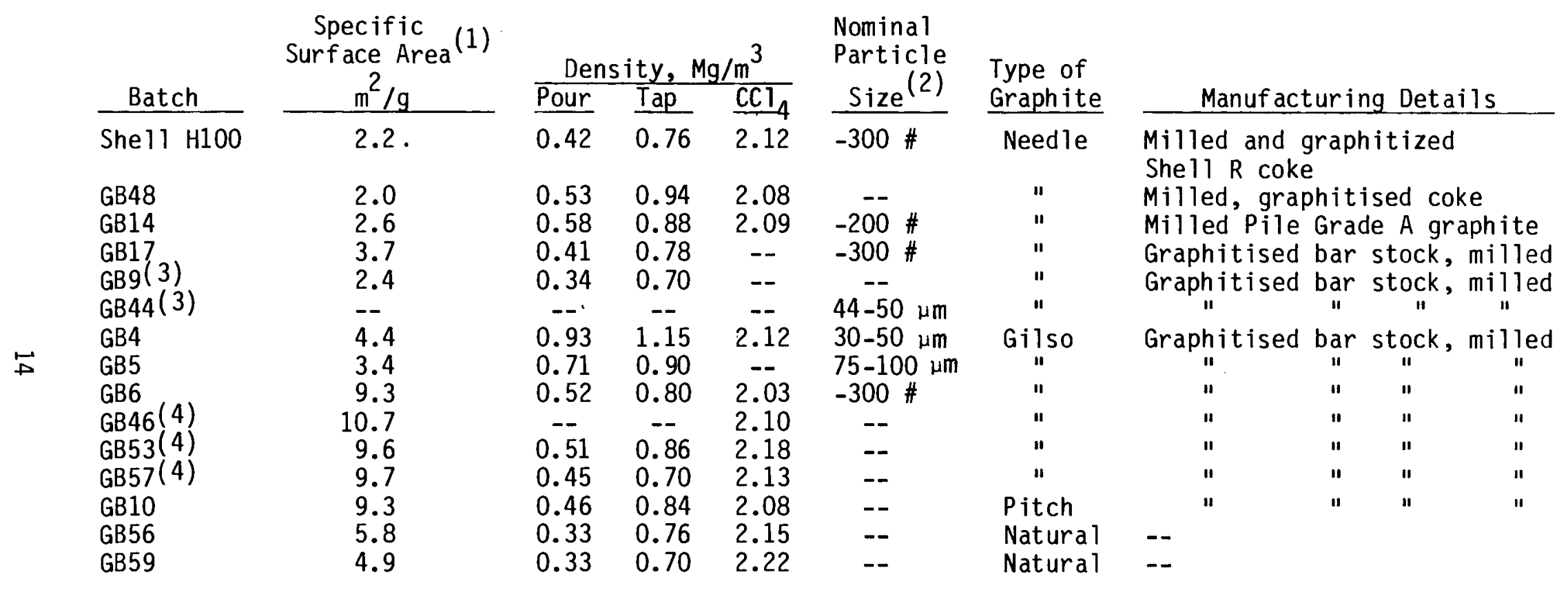

(1) Dynamic method based on BET technique

(2) \# = Sieve mesh designation

(3) GB9 and GB44 are from the same supplier's batch.

(4) GB46, GB53, and GB57 are from the same supplier's batch. 
- A vibratory compacted density as high as $1.40 \mathrm{Mg} / \mathrm{m}^{3}$ can be attained using the presently available commercial graphitized coke powders; i.e., 87.5 percent of the desired density.

- Higher densities could be obtained by either special treatment of the current powders to increase particle density, or by special procurement of selected graphite powders with increased density.

- Ultrasonic resonant vibration of these powders is ineffective in attaining compaction due to rapid attenuation of the signal.

- A mechanical impulse-type vibrator will need to be designed and constructed if vibratory compacted graphite powders are to be used in the FMIT Test Cell shielding. 


\section{REFERENCES}

Ayer, J. E. and F. E. Soppet. 1965. "Vibratory Compaction: I, Compaction of Spherical Shapes." J.Am. Chem. Soc., 48:180.

Ayer, J. E. and F. E. Soppet. 1966. "Vibratory Compaction: II, Compaction of Angular Shapes." J. Am. Chem. Soc., 49:207.

Hauth, J. J. 1962. "Vibration-Compacted Ceramic Fuels." Nucleonics, $\underline{20}(9): 50$.

Hauth, J. J. 1967. "Vibratory Compaction of Nuclear Fuels," Vibratory Compacting - Principles and Methods, Vol. 2, (editors, H. H. Hausner, K. H. Roll and P. K. Johnson), Plenum Press, New York, pp. 258-275.

McGeary, R. K. 1961. Mechanical Packing of Spherical Particles." J. Am. Ceram. Soc., 44:513.

Moore, D. A., C. Bilsby, I. F. Ferguson, and D. E. Y. Walker. 1972. "The Characterization of Graphite Powders Tested for Use in HTR Fuel Compact Matrices," TRG Report $2986(\mathrm{~S})$.

Morgan, W. C., and F. L. Becker. 1979. "Feasibility of Monitoring the Strength of HTGR Core Support Graphite-Part II," NUREG/CR-0995 (PNL-3126). 
APPENDIX A

PRINCIPLES OF VIBRATORY COMPACTION 


\section{APPENDIX A: PRINCIPLES OF VIBRATORY COMPACTION}

For a uniform array of packed spheres of uniform diameter, the theoretical density and the size of the remaining void spaces can be caluclated. Therefore, the diameter of smaller spheres, which will just fill these void spaces, can be calculated. This process can be repeated for a series of smaller spheres, each of which fills the remaining space as efficiently as possible without disturbing the preceding arrays.

Alternately, beginning with the same uniform array of large spheres, one can calculate the maximum diameter of uniform spheres which will infiltrate the voids. The two procedures lead to different diameter ratios and packing fraction. (a) Moreover, in practice, the first procedure requires that a uniform blend of the appropriate particles be added simultaneously; whereas, in the second procedure, each size fraction can be added in sequence.

McGeary (1961) has shown that the prefered packing of uniform-size spheres is in an orthorhombic array with a packed density of 62.5 percent $^{(b)}$ of particle density, if the container diameter is at least 10 times the diameter of the spheres. He produced multi-component packings by sequential infiltration of each finer component. A packed bed of $6 / 7$ mesh spheres was infiltrated with 50/60 mesh spheres, resulting in a packed density of 82.5 percent of particle density; this packed mixture was then infiltrated with $325 / 400$ mesh $^{\text {(b) }}$ particles, resulting in a packed density of 90.0 percent of particle density. The packed mixture was $67 / 23 / 10$ percent by volume for the coarse/medium/fine particles, respectively.

Ayer and Soppet (1965) have shown that the packing efficiency (ratio of packed density to particle density) of uniform-size spheres can be calculated from Equation 1:

$$
P_{1}=0.635-0.216 \mathrm{e}^{-0.313 \mathrm{D} / \mathrm{d}_{1}}
$$

(a) For example, the optimum sphere diameter to fill the spaces in a simple cubic array is $(\sqrt{3-1}) d=0.732 d$, where $d$ is the diameter of the first array of spheres; whereas, the maximum size which will infiltrate is $(\sqrt{2-1}) d=0.414 d$.

(b) Lower packed density was obtained for very small particles; for example: $325 / 400$ mesh tungsten spheres packed only to 59.5 percent. 
Where: $P_{1}=$ packing efficiency,

$D=$ Diameter of the container, and

$\mathrm{d}_{1}=$ diameter of the particles

They have also shown that the packing efficiency of a second-size of spheres, can be calculated from Equation 2:

$$
P_{2}=0.635-0.737 e^{-0.201 d_{1} / d_{2}}
$$

Where: $P_{2}=$ packing efficiency of the second component in the spaces between the first component, and

$\mathrm{d}_{2}=$ diameter of the second component.

The empirical constants in Equations 1 and 2 were generated by fitting the curves to their measured data; 219 data points were used to generate Equation 1 and 60 data points were used to generate Equation 2. Fit of these curves to the data points gave standard deviations of \pm 0.010 and 0.013 , respectively, for the packing efficiency. Moreover Ayer and Soppet (1965) argue that Equation 2 can be applied equally well to multi-component systems and, in the case of 3 components, the average difference between their calculated and measured densities was on $1 y \pm 0.014$.

Irregular shaped particles do not form regular arrays, but tend to $r$ andomly orient and to form bridge-like structures due to friction, wedging, and cohesive forces (which increase as the surface-area-to-volume ratio decreases).

Vibration of sufficient amplitude can overcome these forces and allow the irregular shaped particles to seek an optimum packing density. It should be noted, however, that vibration of excessive amplitude will cause segregation of the particles, with the larger particles rising to the surface, thereby reducing the density.

Ayer and Soppet (1966) conducted packing experiments using malleable steel grit, approximately tetrahedral with one rounded face. The equation used for one-component packing was similar to that used for spherical particles, except for the addition of a shape-factor term. Equation 3 was fit to 105 data points; the standard deviation, for particles larger than $300 \mu \mathrm{m}$, was \pm 0.009 . Packing efficiencies were lower for particles smaller than $300 \mu \mathrm{m}$. 


$$
P_{1}=0.635-0.072 e^{-0.2070 / d_{1}-0.032 / d_{1}}
$$

Where $d_{1}$ is now the average size (in $\mathrm{mm}$ ) of the screen openings in the "thru" and "on" sieves. For the infiltration of a second size-component, 91 data points were fit to Equation 4 with a standard deviation of \pm 0.026 ; however, efforts "to produce uniform density in ternary systems were singularly unsuccessful."

$$
P_{2}=0.484-0.192 e^{-0.098 d_{1} / d_{2}}
$$

Evidently the smaller particles tended to wedge in the irregular openings; this wedging then prevented uniform infiltraton of the third component, resulting in areas of lower density.

Ayer and Soppet (1966) also ran some packing experiments using steel grit which had been ball-milled; these data fell generally between the data for the spheres and that for the angular particles. Maximum packing efficiencies for the three types of particles are shown in Table A.1 (note, however, that lower packing efficiencies were obtained with particles less than about $300 \mu \mathrm{m}$ ).

\begin{tabular}{|c|c|c|c|}
\hline \multirow[b]{2}{*}{$\begin{array}{l}\text { Number of } \\
\text { Components }\end{array}$} & \multicolumn{3}{|c|}{ Maximum Packing Efficiency } \\
\hline & Spheres & $\begin{array}{l}\text { Ball-milled } \\
\text { particles }\end{array}$ & $\begin{array}{l}\text { Angular } \\
\text { grit }\end{array}$ \\
\hline 1 & 0.635 & 0.635 & 0.635 \\
\hline 2 & 0.867 & 0.819 & 0.812 \\
\hline 3 & 0.951 & 0.910 & 0.903 \\
\hline
\end{tabular}

TABLE A.1. Maximum Packing Efficiencies Obtained by Ayer and Soppet

Optimum mix ratios for the three-component systems, calculated from the data in Table A.1, are shown in Table A.2. For two-component mixtures, the optimum ratios would thus be $78 / 22$ for both the ball-milled particles and the angular grit. On the other hand, if the larger graphite particles pack to fill only 54 percent of the space and we infiltrate a smaller particle size which packs to fill only 48 percent of the void space (see Tables 3 and 4 ), we would have a $54 / 22$ mixture (71/29 percent). 
TABLE A.2. Calculated Optimum Mix Ratios

\begin{tabular}{|c|c|c|c|c|}
\hline \multirow{3}{*}{$\begin{array}{c}\text { Size } \\
\text { Fraction } \\
\end{array}$} & \multicolumn{4}{|c|}{ Volume Percent of Mix } \\
\hline & & Dheres & Bal1-mitTed & Angular \\
\hline & (McGeary) & (Ayer \& Soppet) & Particles & Grit \\
\hline coarse & 64.2 & 68.8 & 69.8 & 70.3 \\
\hline medium & 27.0 & 24.4 & 20.2 & 19.6 \\
\hline fine & 8.8 & 8.8 & 10.0 & 10.1 \\
\hline
\end{tabular}




\section{DISTR IBUT ION}

No. of

Copies

A. A. Churm

DOE Patent Group

9800 S. Cass Avenue

Argonne, IL 60439

27 DOE Technical Information Center

ONSITE

DOE Richland Operations Office

H. E. Ransom

P. E. LaMont

6 Hanford Engineering Development Laboratory

R. J. Burke

J. F. Erben

J. W. Hagan

W. L. Knecht (2)

A. L. Trego
No. of

Copies

18 Pacific Northwest Laboratory

C. R. Hann/A. J. Haverfield

P. E. Hart

W. C. Morgan (10)

G. L. Tingey

Technical Information Files (3)

Publishing Coordination (2) 